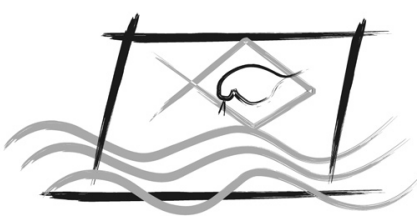

ECOTOX - BRASIL

\title{
Multixenobiotic resistance mechanism monitoring: standardization of fluorescence emmited by Rhodamine B
}

\author{
M.L. Pessatti ${ }^{1,2} * \&$ J.D. Fontana ${ }^{3}$ \\ ${ }^{1}$ Universidade do Vale do Itajaí, Centro de Ciências Tecnológicas da Terra e do Mar (UNIVALI - CTTMar). \\ CEP 88302-202. Itajaí - SC, Brasil. \\ ${ }^{2}$ Universidade Federal do Paraná, Departamento de Bioquímica, Curitiba - PR, Brasil. \\ ${ }^{3}$ Universidade Tecnológica Federal do Paraná - UTFPR - Ecoville, Curitiba - PR, Brasil.
}

(Received April 24, 2012; Accept May 06, 2013)

\begin{abstract}
Many aquatic organisms express the multixenobiotic resistance mechanism (MXR) mediated by a membrane protein denominated P-glycoprotein (Pgp), which reduce the accumulation of xenobiotics by active transport to out of cells. In order to establish fluorescence microscopy as a quantitative method to monitor MXR activity, the kinetic of fluorescence decay emitted by rhodamine B (RB) was determined. Rhodamine B (1 at 1000 nmoles $\mathrm{L}^{-1}$ ) were spotted on silica gel plate and fluorescence decay recorded and determined as exposition time (ET, sec) using a fluorescence microscope's photo sensor. The ET at zero time was obtained from a linear equation of plotting ET(s) against the respective rhodamine B concentrations. The resulting mathematical model $\left(\mathrm{RB}=(28 / \mathrm{ET})-1-\mathrm{Blank}, \mathrm{r}^{2}=0.9945\right)$, allowed the quantitative determination of rhodamine $B$ intracellular accumulation (nmoles $\mathrm{L}^{-1}$ This transport activity quantitation is consequence of the MXR mechanism activity operating in viable sections of gills of the mussel Perna perna and allows its measurement as a molecular biomarker.
\end{abstract}

Keywords: MXR, P-glycoprotein, fluorescence, P. perna, mussel, rhodamine.

Monitoramento do mecanismo de resistência a multixenobióticos: padronização da fluorescência emitida pela rodamina B

\section{Resumo}

Muitos organanismos aquáticos expressam o mecanismo de resistência à multixenobióticos (MXR) mediado pela proteína de membrana denominada glicoproteína-P (Pgp), a qual reduz o acúmulo de xenobióticos por transporte ativo para fora da célula. Com o objetivo de se estabelecer a microscopia como um método quantitativo para monitorar a atividade do mecanismo MXR, a cinética de decaimento da fluorescência emitida pela rodamina B (RB) foi determinada. Soluções de RB (1 a 1000 nmoles $\mathrm{L}^{-1}$ ) foram aplicadas sobre uma placa de sílica gel e as intensidades de fluorescência ao longo do tempo registradas e os resultados expressos como tempo de exposição - ET (segundos) marcados pelo fotosensor de um microscópio de fluorescência. O ET no tempo zero foi obtido de uma equação linear do plote dos ET(s) com as respectivas concentrações de RB. O modelo matemático resultante $\left(\mathrm{RB}=(28 / \mathrm{ET})-1-\mathrm{Branco}, \mathrm{r}^{2}=0.9945\right)$, permitiu a determinação quantitativa do acúmulo intracelular de rodamina $\mathrm{B}\left(\mathrm{nmoles} \mathrm{L}^{-1}\right)$. Esta atividade de transporte é consequência da atividade do mecanismo MXR operando em fragmentos viáveis de brânquias do mexilhão Perna perna e permite seu uso como biomarcador molecular.

Palavras-chave: MXR, glicoproteína-P, fluorescência, P. perna, mexilhão, rodamina.

*Corresponding author: Marcos Luiz Pessatti; e-mail: pessatti@univali.br 


\section{INTRODUCTION}

The multidrug resistance (MDR) mechanism has been verified in many mammalian tumoral cell lines (Cornwall et al., 1995; Marzac et al., 2011; Latorre et al., 2012) and it is the main responsible for cell cross-resistance to multiple cytotoxic agents such as drugs utilized in chemotherapy (Gottesman et al., 1993; Steinbach \& Legrand, 2007). This mechanism is mediated by a protein family, belonging to ATPbinding cassette ( $\mathrm{ABC}$ ) transporters, which pumps (effluxes) xenobiotics out of cells in an ATP-dependent manner. Among these proteins, the P-glycoprotein (Pgp) and multidrug resistance-associated proteins (MRPs) act as transporters in secretory processes, determining the cellular permeability to different structurally unrelated compounds (e.g., cytotoxic, xenobiotics), enhancing the cell resistance to these agents.

Many aquatic organisms express the phenotype of multixenobiotic resistance (MXR) mechanism in a manner analogue to the multidrug resistance (MDR) mechanism (Kurelec \& Pivcevic, 1991; Loncar et al., 2010). The MXR bestow to these animals the capacity of adaptation to contaminated environments. As it is inherently present in all tested aquatic organisms, the MXR mechanism has been considered as a natural biological 'first line' mechanism of defense of protection against xenobiotics (Kurelec et al., 1992).

The activity of MXR mechanism has been quantified by different methods, involving binding assays utilizing radioactive isotopes (Simmons et al., 1995; Kurelec et al., 1997) and fluorescence measurements (Broxterman et al., 1997; Pessatti et al., 2002; Zaja et al., 2011) irrespective to the cells or organisms origin. Rhodamine B is an useful probe as it is recognized as a substrate by Pgp and allows, using activity transport assays, the measurement of the MXR mechanism activity. However, the relationship between the rhodamine B concentration and fluorescence intensity is fundamental for the consolidation of fluorescence microscopy as a quantitative method of MXR mechanism activity. This approach has been used in fresh gill sections of the mussel Perna perna in order to monitor the transport (accumulation and efflux) of the fluorescent dye through in situ experiments.

\section{MATERIAL AND METHODS}

\section{Purification of rhodamine B}

To the purification of rhodamine B P.A. (Merk) was used a conventional chromatographic procedure. The rhodamine $\mathrm{B}$ $(250 \mathrm{mg})$ was fractionated in a column of silica gel (Merk) with $20 \mathrm{~mL}$ (total volume) and eluted with chloroform: methanol (9:1). Fractions of $8 \mathrm{~mL}$ were collected and monitored by thin layer chromatography. The fractions 2-6 were assembled and rechromatographed in same system. The fractions 1 and 2, containing the pure rhodamine $\mathrm{B}$, were concentrated under vacuum.

\section{Standardization of fluorescence emitted by rhodamine B}

To the experiments an eppifluorescence microscope Olympus BX60 equipped with U-MWG filter (excitation and emission wavelengths of 510-550 and $590 \mathrm{~nm}$ respectively) was used. The fluorescence emission with the closed diaphragm from the stained area was quantified by a coupled photo sensor Olympus PM20 regulated at ISO 100 and with a 4.0 exposition adjustment (maximum sensitivity), according Pessatti et al. (2002).

To the standardization of fluorescence emitted by rhodamine $\mathrm{B}$, spots of $10 \mathrm{uL}$ of purified rhodamine $\mathrm{B}$ (from 1 to 1000 nmoles $\left.\mathrm{L}^{-1}\right)$ were carefully applied on silica gel (60 F 254, Riedel-de Haën) plates in order to generate uniform circular areas. The kinetics of fluorescence decay was then recorded from 0 to 90 seconds using the Exposition Time (ET) recorded in the fluorescence microscope's photo sensor as a measurement unit. ET was defined as the necessary time, in seconds, of shutter opening to sensitize a photographic film under the condition described above. A calibration curve was built and the zero time (maximum fluorescence) of each rhodamine B concentration obtained from linear equations of ET plotted against the respective rhodamine $\mathrm{B}$ concentrations. The determinations were performed in triplicate and the results represent the mean of independent experiments (from 2 to 6 ), with the respective confidence intervals $(\alpha=0.05$ ). As a control, the same procedure was performed in silica gel plates spotted with the same volume of distilled water, since it was the solvent used for the dye solubilization.

\section{Assay of rhodamine B transport}

In order to verify the standardization of fluorescence, different assays were assembled using gills of the mussel Perna perna. The mussel specimens (50-70 $\mathrm{mm}$ long) were collected at the Penha Experimental Sea Culture Station, UNIVALI - SC, Brazil, and were acclimatized in laboratory during 24 hours. Rhodamine B accumulation experiments were performed following Cornwall et al. (1995), with some modifications. The mussels were carefully dissected and the gills were collected in filtrated sea water. Small sections $\left(2.5 \mathrm{~mm}^{2}\right)$ were cut from the dorsal edges of the descending arms of each lamella, above the interlamellar tissue bridges, and were incubated in sea water with aeration during 20 minutes for mucus removal. The gill sections were then re-incubated with $2 \mathrm{~mL}$ of $1 \mu$ moles $\mathrm{L}^{-1}$ (or less) rhodamine $\mathrm{B}$ in sea water, for 15 minutes at $16^{\circ} \mathrm{C}$, followed by a $20 \mathrm{sec}$ rinse with sea water in order to discard any extracellular residual dye. Each gill piece was then assembled on a microscope plate. The fluorescence intensity of the abfrontal side of each gill filament was measured in the fluorescence microscope as described. Control for any basal fluorescence was obtained from gill sections incubated in the absence of rhodamine. The fluorescence from fifteen to thirty filaments from each gill section was/were recorded. Final results of the recorded ETs were then expressed as averages and confidence intervals $(\alpha=0.05)$ of the rhodamine $B$ accumulation $\left(n m o l e s \mathrm{~L}^{-1}\right)$ in the gill tissue, calculated respectively from standardization described above. This unit (nmoles $\mathrm{L}^{-1}$ ) should be understood 
as the mass of rhodamine B accumulated in tissue that give a fluorescence intensity equivalent at this concentration when observed in silica gel plate.

\section{RESULTS}

The kinetics of fluorescence decay emitted by purified rhodamine B as function of UV light exposition time is shown in the insert of Figure 1. The ETs at zero times $\left(\mathrm{T}_{0}\right)$ were estimated from the linear equations (mean $\mathrm{r}^{2}=0.9946$ ) obtained by plotting ETs at several times of UV exposition versus the respective concentrations for rhodamine B. Means and confidence intervals $(\alpha=0.05)$ from 2 to 6 independent assays are shown.

Because of the negative exponential profile obtained, many mathematic models were tried to explain the observed behavior. The chosen model to relate ET recorded by the eppifluorescence microscopy and rhodamine $\mathrm{B}$ concentration was:

$$
R B=(28 / E T)-1 \text { - Blank }
$$

(Equation 1)

where RB is the rhodamine $\mathrm{B}$ concentration (in nmoles $\mathrm{L}^{-1}$ ), ET is the exposition time (in seconds) and Blank is the exposition time (in seconds) verified in mussel gills incubated with only sea water (basal fluorescence) (Fig. 2). The $\mathrm{r}^{2}$ to this model was 0.9945 .

\section{DISCUSSION}

The multixenobiotic resistance mechanism is a "first line' of defense against numerous compounds recognized as

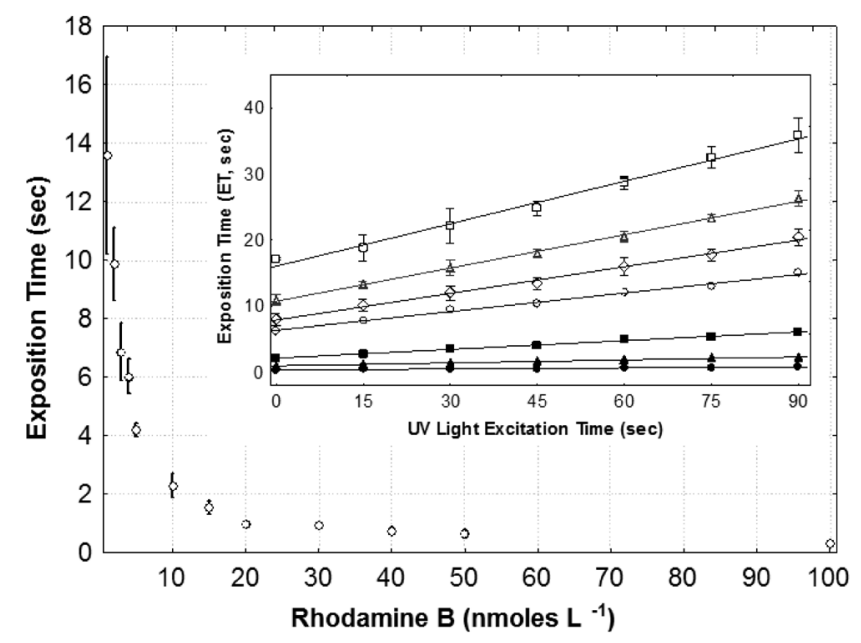

Figure 1 - Calibration curve of fluorescence emitted by purified rhodamine B. Exposition time(s) (ET, seconds) were obtained from different purified rhodamine B concentrations applied to silica gel and exposed to the microscope's UV light at zero time (mean \pm confidence interval $(\mathrm{p}<0.05)$ of 2 from 6 independent assays). Insert: the kinetics of fluorescence decay emitted by purified rhodamine B applied to silica gel when excited by microscope's UV light. ETs mean \pm confidence interval $(\mathrm{p}<0.05)$ obtained from 1 nmoles $\mathrm{L}^{-1}(\square), 2$ nmoles $\mathrm{L}^{-1}(\Delta), 3$ nmoles $\mathrm{L}^{-1}$ $(\diamond), 4$ nmoles L ${ }^{-1}(O), 10$ nmoles L ${ }^{-1}(\boldsymbol{\nabla}), 30$ nmoles $L^{-1}(\Delta)$ and 100 nmoles $\mathrm{L}^{-1}(\bullet)$ purified rhodamine B exposed to UV light in time $(0$ at 90 seconds) in epifluorescence microscope. The results show one of many (from 2 to 6) independent assays, with $\mathrm{r}^{2}$ of 0,9946 (mean of all assays).

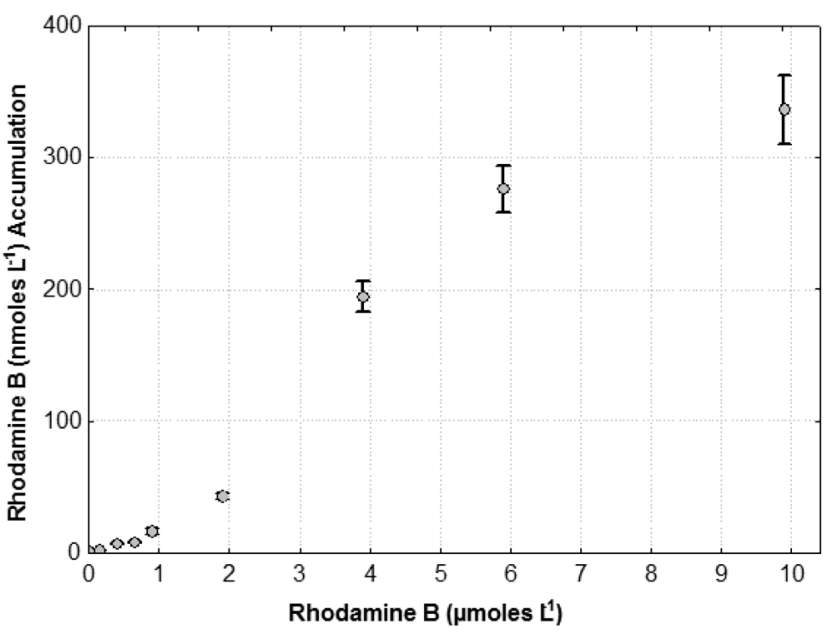

Figure 2 - Saturation of multixenobiotic resistance (MXR) mechanism by purified rhodamine B. Sections gills of mussel $P$. perna were incubated in $2 \mathrm{~mL}$ of rhodamine $\mathrm{B}$ (from 10 nmoles $\mathrm{L}^{-1}$ to $10 \mu$ moles $\mathrm{L}^{-1}$ ) by 30 minutes, washed in sea water to remove any extracellular dye, and then placed on slides for measuring fluorescence intensity.

xenobiotic by cells (Kurelec, 1992). However, to study the MXR in in vivo systems is necessary methods that enable the quantitative determination of transport activity of standard substrates. The rhodamine B is an excellent fluorophore, since is water soluble, is widely used for many purposes (what make it easily available) and has a low cost. Moreover, is a good substrate of Pgp and other ABC transporters (Smital et al., 2003; Nabekura et al., 2010; Faria et al., 2011).

As can be observed, the rhodamine B concentration can be calculated as zero at $\mathrm{ET}=28$ seconds and negative values will be obtained if ET $>28$ seconds (a situation seldom observed experimentally), defining the sensibility limit of the method. Nevertheless, this mathematical model shows a good correlation with ET values as low as 0.03 seconds, which

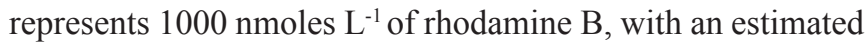
error of $5.83 \%$. The ETs verified in in situ experiments were related with the rhodamine B concentration(s). Hence, Equation 1 allows the quantitative determination of the MXR mechanism activity in in situ experiments.

The results obtained from in situ assays demonstrate the usefulness of this approach as a quantitative method for measuring rhodamine $\mathrm{B}$ in live tissues, and it can be used as expression of MXR mechanism in mussel Perna perna, as well as in other organisms.

\section{REFERENCES}

BROXTERMAN, H.J., SCHUURHUIS, G.J., LANKELMA, J., OBERINK, J.W., EEKMAN, C.A., CLAESSEN, A.M.E., HOEKMAN, K., POOT, M. \& PINEDO, H.M., 1997, Highly sensitive and specific detection of P-glycoprotein function for haematological and solid tumour cells using a novel nucleic acid stain. Br. J. Cancer, 76:1029-1034. http://dx.doi.org/ 10.1038/ bjc. 1997.503

CORNWALL, R., TOOMEY, B. H., BARD, S., BACON, C., JARMAN, W.M. \& EPEL, D., 1995, Characterization of 
multixenobiotic/multidrug transport in the gills of the mussel Mytilus californianus and identification of environmental substrates. Aquat. Toxicol., 31:277-296. http://dx.doi. org/10.1016/0166-445X(94)00070-7

CORNWELL, M. M., GOTTESMAN, M.M. \& PASTAN, I.H., 1986, Increased vinblastine binding to membrane vesicles from multidrug-resistant KB cells. J. Biol. Chem., 261:7921-7928.

FARIA, M., NAVARROA, A., LUCKENBACHB, T., PIÑA, B. \& BARATA, C., 2011, Characterization of the multixenobiotic resistance (MXR) mechanism in embryos and larvae of the zebra mussel (Dreissena polymorpha) and studies on its role in tolerance to single and mixture combinations of toxicants. Aquat. Toxicol., 101:78-87. http://dx.doi.org/10.1016/j.aquatox.2010.09.004

GOTTESMAN, M.M. \& PASTAN, I., 1993, Biochemistry of multidrug resistance mediated by the multidrug transporter. Ann. Rev. Biochem., 62:385-427. http://dx.doi.org/10.1146/annurev. bi.62.070193.002125

NABEKURA, T., YAMAKIA, T., HIROIA, T., UENOA, K. \& KITAGAWAB, S., 2010, Inhibition of anticancer drug efflux transporter P-glycoprotein by rosemary phytochemicals. Pharmacol. Res., 61:259-263. http://dx.doi.org/10.1016/j. phrs.2009.11.010

KURELEC, B. \& PIVCEVIC, B., 1991, Evidence for a multixenobiotic resistance mechanism in the mussel Mytilus galloprovincialis. Aquat. Toxicol., 19:291-302.KURELEC, B., KRCA, S., PIVCEVIC, B., UGARKOVIC, D., BACHMANN, M., IMSIECKE, G. \& MUELLER, W.E.G., 1992, Expression of P-glycoprotein gene in marine sponges. Identification and characterization of the $125 \mathrm{kDa}$ drug-binding glycoprotein. Carcinogenesis, 13:69-76.KURELEC, B., SMITAL, T., BRITVIC, S., PIVCEVIC, B., KRCA, S., JELASKA, S.B., SAUERBORN R. \& MUSTAJBEGOVIC, S., 1997, Multixenobiotic defence mechanism in aquatic organisms. Period. Biol., 99:319-328.

LATORRE, E., TEBALDI, T., VIERO, G., SPARTA, A.M., QUATTRONE, A. \& PROVENZANI A., 2012, Downregulation of $\mathrm{HuR}$ as a new mechanism of doxorubicin resistance in breast cancer cells. Mol. Cancer, 11(1):13. http://dx.doi. org/10.1186/1476-4598-11-13

LONCAR, J., POPOVIĆ, M., ZAJA, R. \& SMITAL, T., 2010, Gene expression analysis of the ABC efflux transporters in rainbow trout (Oncorhynchus mykiss). Comp. Biochem. Physiol. C Toxicol. Pharmacol., 151(2):209-15. http://dx.doi. org/10.1016/j.cbpc.2009.10.009

MARZAC, C., GARRIDO, E., TANG, R., FAVA, F., HIRSCH, P., DE BENEDICTIS, C., CORRE, E., LAPUSAN, S., LALLEMAND, J.Y., MARIE, J.P., JACQUET, E. \& LEGRAND, O., 2011, ATP Binding Cassette transporters associated with chemoresistance: transcriptional profiling in extreme cohorts and their prognostic impact in a cohort of 281 acute myeloid leukemia patients. Haematologica, 96(9):1293-301. http://dx.doi.org/10.3324/ haematol.2010.031823

PESSATTI, M. L., RESGALLA JR., C., REIS FO, R.W., KUEHN, J. \& FONTANA, J.D., 2002, Variability of rates of filtration, respiration and assimilation and of multixenobiotic mechanism resistance (MXR) of mussel Perna perna under lead influence. Braz. J. Biol., 62(4A):651-656. http://dx.doi.org/10.1590/S151969842002000400013

SIMMONS, N.L., HUNTER, J. \& JEPSON, M.A., 1995, Targeted delivery of a substrate for P-glycoprotein to renal cysts in vitro. Biochem. Biophys. Acta, 1237:31-36.

SMITAL, T., SAUERBORN, R. \& HACKENBERGER, B.K., 2003, Inducibility of the P-glycoprotein transport activity in the marine mussel Mytilus galloprovincialis and the freshwater mussel Dreissena polymorpha. Aquat. Toxicol., 65:443-465. http:// dx.doi.org/10.1016/S0166-445X(03)00175-9

ZAJA, R., LONČAR, J., POPOVIC, M. \& SMITAL, T., 2011, First characterization of fish P-glycoprotein (abcb1) substrate specificity using determinations of its ATPase activity and calceinAM assay with PLHC-1/dox cell line. Aquat. Toxicol., 103(12):53-62. http://dx.doi.org/10.1016/j.aquatox.2011.02.005 